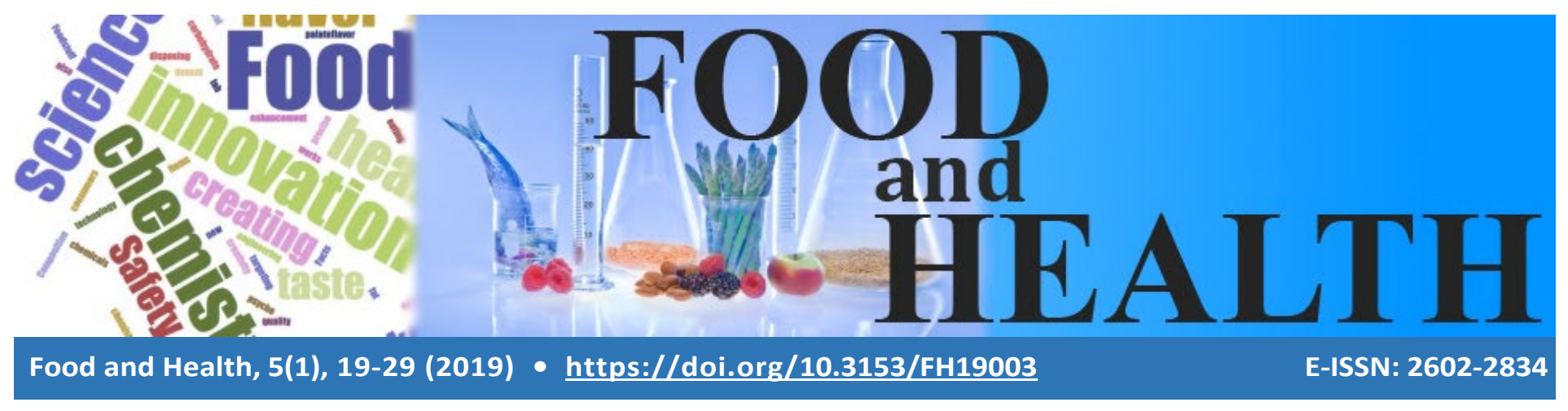

Research Article

\title{
BIOGENIC AMINE CONTENTS OF FRESH AND MATURE KASHAR CHEESES DURING REFRIGERATED STORAGE
}

\author{
Songül Şahin Ercan ${ }^{(D)}$, Çiğdem Soysal ${ }^{\circledR}$, Hüseyin Bozkurt ${ }^{\circledR}$
}

Cite this article as:

Şahin Ercan, S., Soysal, Ç., Bozkurt, H. (2019). Biogenic Amine Contents of Fresh and Mature Kashar Cheeses During Refrigerated Storage. Food and Health, 5(1), 19-29. https://doi.org/10.3153/FH19003

Department of Food Engineering, Faculty of Engineering, University of Gaziantep, 27310 Gaziantep, Turkey

Submitted: 21.11 .2017

Accepted: 30.03 .2018

Published online: 08.08.2018

Correspondence:

Çiğdem SOYSAL

E-mail: aykac@gantep.edu.tr

๑Copyright 2019 by ScientificWebJournals

Available online at http://jifhs.scientificwebjournals.com

\begin{abstract}
Kashar is one of the most consumed traditional cheeses in Turkey. It is produced as fresh or mature, which differ in ripening periods. Safe consumption period of kashar was investigated during refrigerated storage. Five samples of fresh and five samples of mature kashar cheeses collected from local supermarkets in Turkey were analyzed. Changes in biogenic amines, $\mathrm{pH}$ and thiobarbituric acid reactive substance of fresh and mature kashar cheeses were investigated during storage. Mature kashar cheeses had higher biogenic amine concentrations than fresh kashar cheeses. During storage, total biogenic amine contents of all samples increased significantly $(\mathrm{p}<0.05)$. Total biogenic amine contents of mature kashar cheeses were higher than maximum allowed limit of $1000 \mathrm{mg} / \mathrm{kg}$ and can cause toxicity. It was found that fresh kashar cheeses were safer than mature kashar cheeses with respect to the toxic limits of biogenic amines.
\end{abstract}

Keywords: Fresh kashar, Mature kashar, Cheese, Biogenic amines 


\section{Introduction}

Kashar, a semi-hard Turkish traditional cheese, is one of the most consumed cheeses in Turkey (Koca \& Metin, 2004). According to Turkish Statistical Institute, total cheese production of Turkey was 665580 tonnes in 2015, and semihard cheese production was 191206 tones (Anonymous, 2005). The reasons of popularity are long shelf life and flavor. It has similar characteristics with Caciocavalle, Provolone, Regusono, Kashkaval cheeses and with the 'Pasta Filata' type cheese such as Mozarella partially (Halkman \& Halkman, 1991). Some researchers mentioned similarity between Cheddar and Kashar Cheese (Çetinkaya et al., 2003).

According to Turkish Standards, Kashar cheese is classified as "fresh" and "old or mature" in terms of ripening (Turkish Standards Institute, (TSI), 1999). Both types can be eaten at breakfast; however the fresh cheese is also consumed in toasted sandwiches or baked foods in the same way as Mozzarella cheese (Çetinkaya et al, 2003; Üçüncü 2004). Mature kasar cheese is traditionally produced in $27-30 \mathrm{~cm}$ diameter and $10-13 \mathrm{~cm}$ height and $6-10 \mathrm{~kg}$ weight. Traditionally, kashar cheese is made from raw sheep or cows' milk or their mixtures without the addition of starter cultures. The traditional method involves renneting, curd forming, curd fermentation (about $\mathrm{pH} 5.1-5.4$ ), scalding and texturing of the curd in hot water $\left(65-80^{\circ} \mathrm{C}\right)$ containing $6-8 \% \mathrm{NaCl}$, shaping of the scalded curd, pre-ripening at $15-20^{\circ} \mathrm{C}$ and ripening at $2-4^{\circ} \mathrm{C}$ for at least 3 months (Aran, 1998). Mature Kashar cheese is consumed after long term ripening, and it is believed that the cheese gains its characteristic flavour after 6 to 12 months. During this period dry salting is applied over the surface of cheese. Production of mature kashar cheese requires more labour force and time, reduce yield due to water loss during ripening period (Sert et al., 2007).

Amino acids provide carbon, nitrogen and energy sources for bacterial cells and play an important role in the development of flavour in cheeses. Cheese is an ideal substrate for amine production. It contains the high free amino acids concentration as a result of proteolysis, availability of amino acid decarboxylase producing microorganisms, adequate temperature, $\mathrm{pH}$, cofactor and water activity (Benkerroum, 2016). Other factors affecting the production of biogenic amines in cheeses include the presence of spoilage microorganisms and the synergistic effects between microorganisms. Moreover several extrinsic factors may also play an important role, namely, pasteurization of milk, salt-in-moisture levels and ripening time (Linares et al., 2013). In particular, the $\mathrm{pH}$ of cheese (5.0-6.5) is optimum for the activity of most decarboxylases and it has been found that the production of biogenic amines is accelerated by high temperatures during production and manufacture of cheese and by the prolonged aging process (Spizzirri et al., 2013). Biogenic amines are organic, basic, nitrogenous compounds (Şahin Ercan et al., 2013). Free amino acid decarboxylation leads to biogenic amine formation (Flasarova et al., 2016). Importance of biogenic amines in foods is mainly due to two reasons; firstly, the intake of foods containing high content of biogenic amines cause health hazard through the direct, toxic effect of these compounds and their interaction with some medicaments; secondly, they may have a role as indicators of quality and/or acceptability in some foods (Shalaby, 1996; Ruiz-Capillas \& Moral, 2001; Şahin Ercan et al., 2013). The presence of low levels of biogenic amines in cheeses and other foods is not considered as serious risk. However, high amount of biogenic amine consumption may result in various physiological effects (Koehler et al., 1978). Several outbreaks of histamine poisoning have occurred following the consumption of cheese, particularly Swiss and Cheddar, containing high levels of histamine (Vale \& Gloria, 1998). There is a term that is called "Cheese reaction" is a hypertensive crisis. It's characterized by a release of catecholamines from the sympathetic nervous system and the adrenal medulla, both causing an increase of the mean arterial blood pressure $(\geq 180 / 120 \mathrm{mmHg})$ and heart rate by peripheral vasoconstriction, producing hypertensive crisis as more dangerous consequence. Its certain symptom is severe headache, has been observed after ingestion of foods rich in tyramine (Vale \& Gloria 1998; Linares et al., 2013).

To the best of our knowledge, any study about biogenic amine contents of fresh and mature kashar cheeses during storage period has not been found in the literature. The aim of this study was to determine the changes in some quality $(\mathrm{pH}$, protein, ripening index $(\mathrm{RI})$, total nitrogen $(\mathrm{TN})$, water soluble nitrogen (WSN), salt and moisture content) and safety (thiobarbituric acid reactive substance and biogenic amines) parameters of cheeses during storage period and also to compare fresh and mature kashar cheeses.

\section{Materials and Methods}

\section{Sampling}

Ten randomly purchased commercial kashar cheeses produced in Turkey were analysed. Five of them were fresh (S1, $\mathrm{S} 2, \mathrm{~S} 3, \mathrm{~S} 4$ and S5) and the other five were mature kashar (S6, S7, S8, S9 and S10) cheeses. Kashar cheeses were stored at $4 \pm 1^{\circ} \mathrm{C}$ for three weeks and samples were taken for analysis at $0,1,2$ and $3^{\text {th }}$ weeks of storage. Kashar cheeses were analyzed for biogenic amines (cadaverine, histamine, 
phenylethylamine, tyramine, tryptamine, putrescine and spermidine), $\mathrm{pH}$, moisture content and TBARS values. Initial protein, WSN, TN and salt contents were also determined. The kashar cheeses were grated, homogenized using the Waring blender thoroughly and analyzed immediately. Each analysis was performed at least in dublicate.

\section{Chemicals}

1,1,3,3-Tetraethoxypropane (TEP) and 2-thiobarbituric acid were obtained from Sigma (St. Louis, MO); $\beta$-phenylethylamine hydrochloride, histamine dihydrochloride, cadaverine dihydrochloride, spermidine, putrescine dihydrochloride, tryptamine hydrochloride and tyramine hydrochloride were obtained from Sigma (St. Louis, MO) and were used as biogenic amine standards; sodium hydroxide, $25 \%$ ammonium and sodium bicarbonate were from Merck (Darmstadt, Germany), acetone from Reidel De Haen (Germany), dansyl chloride from Sigma Co. (St. Louis, MO), ammonium acetate from Merck (Darmstadt, Germany), and perchloric acid from JT Baker (Holland). All chemicals except acetonitrile were analytical grade (extra pure) and acetonitrile was HPLC grade.

\section{Determination of Cheese Characteristics}

Moisture content, total nitrogen, water soluble nitrogen, ripening index, salt contents and $\mathrm{pH}$ of cheese samples were determined in triplicate runs. Moisture content of cheeses was determined according to AACC, 1995 Approved Methods. The cheese samples were analysed for TN using Kjeldahl method (AOAC, 1990) with digestion, distillation and titration steps. The protein content of cheeses was calculated by multiplying the total nitrogen content by 6.38 . WSN of kashar cheese samples were determined as described by Butikofer et al, (1993). RI of samples was calculated from the ratio of water soluble nitrogen to total nitrogen (Butikofer et al., 1993). Salt content was determined by the Mohr method (AOAC, 1990). pH value of kashar cheese was determined using a $\mathrm{pH}$ meter (Jenway 3010; Jenway Ltd., Essex, UK) equipped with an electrode (J95, 924001, Jenway Ltd., Essex, UK).

\section{Determination of TBARS (2-Thiobarbituric Acid Reactive} Substances) Values

TBARS of samples were determined by the spectrophotometric method (Bozkurt \& Erkmen, 2004). Two grams of homogenized kashar samples were taken and TBARS were extracted twice with $10 \mathrm{~mL}$ of $0.4 \mathrm{M}$ perchloric acid. Extracts were collected and made up to $25 \mathrm{~mL}$ with $0.4 \mathrm{M}$ perchloric acid and centrifuged for $5 \mathrm{~min}$ at $1790 \mathrm{~g}$. After centrifugation, $1 \mathrm{~mL}$ of supernatant was pipetted into glass stoppered test tube. TBA reagent $(5 \mathrm{~mL})$ was added and the mixture was heated in a boiling water bath for $35 \mathrm{~min}$. After cooling the absorbance of sample was read against the appropriate blank at $538 \mathrm{~nm}$. A standard curve was prepared using 1,1,3,3-tetraethoxypropane (TEP). TBARS values were determined as mg malondialdehyde (MA) $/ \mathrm{kg}$ sample.

\section{Determination of Biogenic Amines}

The chromatographic method (Eerola et. al., 1993) was used for the determination of the biogenic amines. The HPLC consisted of a Shimadzu gradient pump (Shimadzu LC 20AB, Shimadzu Solvent Delivery Module, Kyoto, Japan), a Shimadzu auto injection unit (Shimadzu SIL20AHT, Kyoto, Japan), a Shimadzu UV detector (Shimadzu SPD 20A, Kyoto, Japan) and a RP-18 guard column. The HPLC column was Spherisorb ODS2, $200 \mu \mathrm{m}$ and $4.6 \mathrm{~mm} \times 200$ $\mathrm{mm}$. Ammonium formate solution $(0.4 \mathrm{M})$ prepared by ultra-pure water (Millipore Elix 10UV and Milli-Q, Millipore S.A.S. 67120 Molsheim, France) and acetonitrile were filtered through a $0.45 \mu \mathrm{m}$ millipore filter (Billerica, MA). Ammonium formate and acetonitrile were used as the LC mobile phases. A gradient elution program was used with mobile phases of acetonitrile (solvent $\mathrm{A}$ ) and $0.4 \mathrm{M}$ ammonium formate (solvent $\mathrm{B}$ ), starting with $50 \%$ solvent $\mathrm{A}$ and $50 \%$ solvent B and finishing with $90 \%$ solvent $\mathrm{A}$ and $10 \%$ solvent B after $35 \mathrm{~min}$. The flow rate was $1.0 \mathrm{~mL} / \mathrm{min}$.

Two grams of sample was homogenized in $10 \mathrm{~mL}$ of $0.4 \mathrm{M}$ perchloric acid using a Waring blender. The sample was centrifuged for $10 \mathrm{~min}$ at $1790 \mathrm{~g}$ and filtered. The extraction was repeated with a further $10 \mathrm{~mL}$ of $0.4 \mathrm{M}$ perchloric acid solution and the supernatants were combined and made up to $25 \mathrm{~mL}$ with $0.4 \mathrm{M}$ perchloric acid. One millilitres of extract was pipetted into glass stoppered test tube and $200 \mu \mathrm{L}$ of $2 \mathrm{~N} \mathrm{NaOH}$ and $300 \mu \mathrm{L}$ of saturated sodium bicarbonate solutions were added. Two millilitres of dansyl chloride (10 $\mathrm{mg} / \mathrm{mL}$ ) solution was added to each sample and incubated for $45 \mathrm{~min}$ at $40^{\circ} \mathrm{C}$. Residual dansyl chloride was removed by adding $100 \mu \mathrm{L}$ of $25 \%$ ammonia. After $30 \mathrm{~min}$, the solution was adjusted to $5 \mathrm{~mL}$ with acetonitrile, centrifuged for $5 \mathrm{~min}$ at $1790 \mathrm{~g}$, the supernatant filtered $(0.45 \mu \mathrm{m})$ and 20 $\mu \mathrm{L}$ then injected onto the HPLC. The standard solution of the dansylated derivatives was diluted to $1 \mathrm{~mL}$ with $0.4 \mathrm{M}$ perchloric acid to give concentrations from 0.5 to $10 \mu \mathrm{g} / \mathrm{mL}$.

\section{Statistical Analysis}

The results were analyzed statistically using the SPSS 13.0 for Windows (SPSS Inc., Chicago, IL, USA). The one-way analysis of variance (ANOVA test) and Duncan's multiple range test were performed. Values of $p<0.05$ were used to indicate significant differences. 


\section{Results and Discussion}

\section{Cheese Characteristics}

Table 1 shows the results obtained from the analysis of fresh and mature kashar cheeses at the beginning of the storage period. Salt content of cheeses were changed beetwen 1.35.0\%. The Turkish Food Codex (No: 2015/6) states that fresh and mature kashar cheeses should have salt values up to 3.0 and $4.0 \%$, respetively (Anonymous, 2005). Salt content of fresh kashar cheeses detected in this study is not suited to the Turkish Food Codex. It was reported that kashar cheeses contain an average of 2.54-5.24\% salt Sert et al. (2007). On the other hand, salt contents of fresh kashar cheese were significantly higher $(p<0.05)$ than the mature kashar cheeses. This could be due to the differences in production of mature and fresh kashar cheeses. Also, moisture content range of both mature and fresh kashar cheese were in the range of $37.9-46.1 \%$ which is suited to the reported range of 29.18-57.29\% (Sert et al., 2007). According to the results, moisture contents of mature kashar cheeses (37.9$41.6 \%$ ) was lower than fresh kashar cheeses (43.3-46.1\%). This could be due to dry salting process over the surface of mature kashar cheeses during the ripening period (6-12 months). Results showed that generally higher values of TN, WSN, RI and protein were obtained for mature kashar cheeses (Table 1). Obtaining higher values of TN, WSN, RI and protein in mature kashar cheeses could be due to longer proteolsis. Proteolysis is the most complex and important biochemical event that occurs in most cheeses during ripening. It has direct influence on flavour and texture as softening of cheese during ripening (McSweeney, 2004). The evolution of the WSN/TN could be interpreted as the level of proteolysis (Sert et al., 2007) which correspounds to RI.

\section{Changes of $p H$ and TBARS Values}

Changes of $\mathrm{pH}$ and TBARS values during the storage periods of kashar samples are given in Table 2 . The $\mathrm{pH}$ values of fresh and mature kashar cheese samples were not affected significantly $(p>0.05)$ and remained almost constant during refrigerated storage. TBARS values is used as a marker of lipid oxidation. Degradation of polyunsaturated fatty acids results in malonaldehyde formation. Lipid oxidation could cause destruction of valuable nutrients, off-flavours and production of toxic compounds (Medeiros et al., 2014). Consequently, TBARS value is a critical parameter especially during storage period of foods that's why it is detected in this study. It could cause adverse sensorial results which affects consumer acceptance. TBARS values were affected significantly $(p<0.05)$ by storage. As the storage period prolong, TBARS values of all cheese samples increased. Initial range of TBARS value of fresh kashar cheeses were 0.03$0.18 \mathrm{mg} / \mathrm{kg}$ and increased to $0.20-0.39 \mathrm{mg} / \mathrm{kg}$ at the end of the storage period. This range was $0-0.15 \mathrm{mg} / \mathrm{kg}$ and $0.23-$ $0.57 \mathrm{mg} / \mathrm{kg}$ for mature kashar cheeses at the beginning and end of the storage period, respectively. Lipid oxidation leads through formation of hydroperoxides to short chain aldehyde, ketones and other oxygenated compounds. They are considered to be responsible for the development of rancidity, cause undesirable flavour and related to heart disease and cancer (Botsoglou et al., 1994). Change in the TBARS values of mature kashar cheeses were higher than that in the fresh kashar cheeses during the storage period. It was reported that if the TBARS value is higher than $1 \mathrm{mg} / \mathrm{kg}$, generally off-odors are formed and it is considered as the begining of organoleptic perception of lipid oxidation ( $\mathrm{Wu}$ et al., 1991). None of the samples exceed this limit during 2 weeks refrigerated storage period.

\section{Biogenic Amines Content}

\section{Changes in Histamine Concentration}

Changes of histamine concentration and their statistical analysis are given in Tables 3 and 4, for fresh and mature kashar cheeses, respectively. Histamine concentration changed significantly $(p<0.05)$ with storage time. Initial histamine concentration range of fresh and mature kashar cheeses are 29.0-76.4 $\mathrm{mg} / \mathrm{kg}$ (Table 3) and 52.8-1334.4 $\mathrm{mg} / \mathrm{kg}$ (Table 4), respectively. At the end of the storage period, this range changed as 45.4-145.9 mg/kg and 270.15$3042.9 \mathrm{mg} / \mathrm{kg}$ for fresh and mature kashar cheeses, respectively. Mean of initial histamine concentration of fresh kashar cheeses $(60.8 \mathrm{mg} / \mathrm{kg})$ was similar to histamine concentration $(63.5 \mathrm{mg} / \mathrm{kg})$ in Gouda cheese (Silvana et al., 1998), but mean of initial histamine concentration of mature kashar cheeses $(525.5 \mathrm{mg} / \mathrm{kg})$ were high.

During the storage period, histamine concentration increased $(p<0.05)$ for both fresh and mature kashar cheeses (Table 3 and 4). Substrate availability could be an accelerating factor for histamine production in cheese (Joosten, 1998). Also, the use of raw milk or post-contamination in cheese may result in high levels of histamine formation (Stratton et al., 1992). It was reported that histamine intake of 8-40 mg, 40-100 $\mathrm{mg}$ and higher than $100 \mathrm{mg}$ may cause slight, intermediate and intensive poisoning, respectively (Nout, 1994). According to the results, consumption of fresh kashar cheeses samples at the beginning of the storage period may cause slight or intermediate poisoning with respect to the their histamine levels. However, consumption of mature kashar cheeses at the beginning of storage period may cause intensive poisoning. 
Table 1. Initial characteristics of kashar cheese samples before storage

\begin{tabular}{lllllll}
\hline Sample & TN $(\%)$ & WSN $(\%)$ & Protein $(\%)$ & Salt $(\%)$ & RI $(\%)$ & Moisture $(\%)$ \\
\hline S1 & $4.2 \pm 0.2 \mathrm{~cd}$ & $0.9 \pm 0.04 \mathrm{a}$ & $26.0 \pm 1.5 \mathrm{bcd}$ & $4.2 \pm 0.2 \mathrm{a}$ & $21.4 \pm 0.3 \mathrm{a}$ & $43.3 \pm 0.7 \mathrm{a}$ \\
S2 & $3.7 \pm 0.2 \mathrm{abc}$ & $0.9 \pm 0.05 \mathrm{a}$ & $23.4 \pm 1.5 \mathrm{abc}$ & $4.8 \pm 0.5 \mathrm{ab}$ & $24.3 \pm 3.2 \mathrm{ab}$ & $45.6 \pm 0.1 \mathrm{c}$ \\
S3 & $3.4 \pm 0.1 \mathrm{a}$ & $0.8 \pm 0.05 \mathrm{a}$ & $21.4 \pm 0.6 \mathrm{a}$ & $4.3 \pm 0.5 \mathrm{a}$ & $23.5 \pm 2.1 \mathrm{ab}$ & $45.1 \pm 0.2 \mathrm{c}$ \\
S4 & $4.2 \pm 0.5 \mathrm{~cd}$ & $1.1 \pm 0.05 \mathrm{~b}$ & $26.2 \pm 3.0 \mathrm{~cd}$ & $4.6 \pm 0.4 \mathrm{ab}$ & $26.1 \pm 4.2 \mathrm{~b}$ & $44.0 \pm 0.5 \mathrm{~b}$ \\
S5 & $3.8 \pm 0.1 \mathrm{abc}$ & $0.8 \pm 0.0 \mathrm{a}$ & $23.8 \pm 0.3 \mathrm{abc}$ & $5.0 \pm 0.1 \mathrm{~b}$ & $21.1 \pm 0.3 \mathrm{a}$ & $46.1 \pm 0.4 \mathrm{c}$ \\
\hline S6 & $3.5 \pm 0.3 \mathrm{a}$ & $1.7 \pm 0.1 \mathrm{cb}$ & $22.3 \pm 1.8 \mathrm{a}$ & $3.3 \pm 0.2 \mathrm{c}$ & $48.5 \pm 5.7 \mathrm{c}$ & $41.6 \pm 0.1 \mathrm{c}$ \\
S7 & $4.3 \pm 0.1 \mathrm{ab}$ & $1.9 \pm 0.01 \mathrm{c}$ & $26.9 \pm 0.3 \mathrm{~b}$ & $1.9 \pm 0.4 \mathrm{ab}$ & $44.1 \pm 1.2 \mathrm{bc}$ & $40.5 \pm 0.1 \mathrm{c}$ \\
S8 & $3.9 \pm 0.3 \mathrm{a}$ & $1.3 \pm 0.0 \mathrm{a}$ & $25.1 \pm 2.1 \mathrm{ab}$ & $2.5 \pm 0.1 \mathrm{~b}$ & $33.3 \pm 1.9 \mathrm{a}$ & $39.9 \pm 0.8 \mathrm{a}$ \\
S9 & $4.5 \pm 0.1 \mathrm{~b}$ & $1.9 \pm 0.01 \mathrm{c}$ & $30.2 \pm 0.6 \mathrm{c}$ & $1.9 \pm 0.2 \mathrm{ab}$ & $42.2 \pm 2.3 \mathrm{~b}$ & $39.4 \pm 0.1 \mathrm{a}$ \\
S10 & $4.5 \pm 0.1 \mathrm{~b}$ & $1.5 \pm 0.02 \mathrm{~b}$ & $28.4 \pm 0.6 \mathrm{c}$ & $1.3 \pm 0.1 \mathrm{a}$ & $33.3 \pm 5.1 \mathrm{a}$ & $37.9 \pm 0.9 \mathrm{~b}$ \\
\hline
\end{tabular}

Different small letters indicate statistical difference at $\alpha=0.05$ level in each column.

S1- S5 are fresh kashar and S6-S10 are old kashar cheeses.

Table 2. Changes of $\mathrm{pH}$ and TBARS values of fresh and mature kashar cheeses during storage.

\begin{tabular}{lccccccc}
\hline Sample & \multicolumn{2}{c}{$\mathrm{pH}$} & & \multicolumn{3}{c}{ TBARS } \\
\cline { 3 - 4 } & 0 & $1^{\text {st }} w e e k$ & $2^{\text {nd }} w e e k$ & 0 & $1^{\text {st }}$ week & $2^{\text {nd }} w e e k$ \\
\hline S1 & $5.68 \pm 0.28 \mathrm{a}$ & $5.89 \pm 0.21 \mathrm{a}$ & $5.76 \pm 0.24 \mathrm{a}$ & $0.13 \pm 0.04 \mathrm{a}$ & $0.26 \pm 0.00 \mathrm{~b}$ & $0.33 \pm 0.04 \mathrm{~b}$ \\
S2 & $5.73 \pm 0.26 \mathrm{a}$ & $5.81 \pm 0.18 \mathrm{a}$ & $5.76 \pm 0.24 \mathrm{a}$ & & $0.05 \pm 0.00 \mathrm{a}$ & $0.13 \pm 0.04 \mathrm{ab}$ & $0.21 \pm 0.00 \mathrm{~b}$ \\
S3 & $6.05 \pm 0.15 \mathrm{a}$ & $6.16 \pm 0.18 \mathrm{a}$ & $6.11 \pm 0.28 \mathrm{a}$ & & $0.05 \pm 0.00 \mathrm{a}$ & $0.13 \pm 0.04 \mathrm{ab}$ & $0.23 \pm 0.04 \mathrm{~b}$ \\
S4 & $5.96 \pm 0.30 \mathrm{a}$ & $6.07 \pm 0.19 \mathrm{a}$ & $6.06 \pm 0.25 \mathrm{a}$ & & $0.03 \pm 0.01 \mathrm{a}$ & $0.28 \pm 0.04 \mathrm{~b}$ & $0.36 \pm 0.00 \mathrm{c}$ \\
S5 & $5.39 \pm 0.27 \mathrm{a}$ & $5.57 \pm 0.21 \mathrm{a}$ & $5.54 \pm 0.19 \mathrm{a}$ & & $0.18 \pm 0.04 \mathrm{a}$ & $0.28 \pm 0.04 \mathrm{~b}$ & $0.39 \pm 0.04 \mathrm{c}$ \\
\hline S6 & $5.48 \pm 0.24 \mathrm{a}$ & $5.54 \pm 0.23 \mathrm{a}$ & $5.60 \pm 0.16 \mathrm{a}$ & & $0.05 \pm 0.00 \mathrm{a}$ & $0.13 \pm 0.04 \mathrm{ab}$ & $0.23 \pm 0.04 \mathrm{~b}$ \\
S7 & $5.37 \pm 0.27 \mathrm{a}$ & $5.48 \pm 0.22 \mathrm{a}$ & $5.75 \pm 0.19 \mathrm{a}$ & & $0.10 \pm 0.00 \mathrm{a}$ & $0.33 \pm 0.04 \mathrm{~b}$ & $0.41 \pm 0.00 \mathrm{c}$ \\
S8 & $5.34 \pm 0.24 \mathrm{a}$ & $5.45 \pm 0.22 \mathrm{a}$ & $5.60 \pm 0.19 \mathrm{a}$ & & $0.13 \pm 0.04 \mathrm{a}$ & $0.23 \pm 0.04 \mathrm{~b}$ & $0.33 \pm 0.04 \mathrm{c}$ \\
S9 & $5.52 \pm 0.24 \mathrm{a}$ & $5.76 \pm 0.18 \mathrm{a}$ & $6.80 \pm 0.26 \mathrm{a}$ & & $0.15 \pm 0.00 \mathrm{a}$ & $0.39 \pm 0.11 \mathrm{~b}$ & $0.57 \pm 0.00 \mathrm{c}$ \\
S10 & $5.50 \pm 0.18 \mathrm{a}$ & $5.90 \pm 0.20 \mathrm{a}$ & $5.94 \pm 0.21 \mathrm{a}$ & & $0.00 \pm 0.00 \mathrm{a}$ & $0.15 \pm 0.00 \mathrm{~b}$ & $0.26 \pm 0.07 \mathrm{~b}$ \\
\hline
\end{tabular}

Different small letters indicate statistical difference at $\alpha=0.05$ level in each column.

S1- S5 are fresh kashar and S6-S10 are old kashar cheeses.

\section{Changes in Phenylethylamine Concentration}

The level of phenyethylamine concentration was changed significantly $(p<0.05)$ during the storage period (Tables 3 and 4). Concentrations of phenylethylamine of fresh and mature kashar cheeses increased simultaneously. From a good manufacturing practice point of view, a level of 30 $\mathrm{mg} / \mathrm{kg}$ of phenylethylamine concentration is regarded as acceptable (Nout, 1994). In this study, phenylethylamine concentration exceeded a concentration of $30 \mathrm{mg} / \mathrm{kg}$ even at the beginning and end of the storage period for both fresh and mature kashar cheeses. It was reported that phenylethylamine was not detected in kashar (Andiç et al., 2011), but was found in 19 of 30 herby cheeses samples (Andiç et al., 2010a) and never exceeded a concentration of $30 \mathrm{mg} / \mathrm{kg}$ in motal cheeses (Andiç et al., 2010b).

\section{Changes in Tyramine Concentration}

Tyramine, one of the toxicologically important biogenic amines, is formed in foods by the action of tyrosine decarboxylase produced by bacteria associated with the foods (Silla-Santos, 1996). The allowable maximum level of tyramine in food is $100-800 \mathrm{mg} / \mathrm{kg}$. Concentrations of 1080 $\mathrm{mg} / \mathrm{kg}$ of tyramine are toxic for humans (Shalaby, 1996). Changes in tyramine concentrations and results of statistical analysis during the storage period are given in Tables 3 and 4 for fresh and mature kashar cheeses, respectively. During the storage period tyramine concentration increased significantly $(p<0.05)$ for both fresh and mature kashar cheese samples. The levels of tyramine conentrations in fresh kashar cheeses were acceptable during the storage period. However, mature kashar cheeses had higher tyramine concentration compared to fresh kashar cheeses. Tyramine concentration of mature kashar cheese sample S9 was found 
very high $(>800 \mathrm{mg} / \mathrm{kg})$ before and during storage period. This could be due to the presence of high amount of tyrosine and tyrosine decarboxylase activity and poor sanitation during processing. It was reported that any food with free amino acids, especially tyrosine and phenylalanine, are subject to biogenic amine formation if poor sanitation and low quality foods are used or if the food is subjected to temperature abuse or extended storage time (Schirone et al., 2011). High amounts of tyramine were found in Spanish traditional cheeses (Roig-Sagues et al., 2002). It was reported that despite the high concentrations of the precursor amino acid tyrosine in cheeses, they do not provide evidence of tyramine in their biogenic amine inventory (Pintado et al., 2008). During fermentation and ripening, the environmental factors that affect the activity of decarboxylating enzymes may be more important than precursor availability (Schirone et al., 2011). Tyramine levels in Tulum cheese ranged and was almost from 109.6 to $1575.5 \mathrm{mg} / \mathrm{kg}$ (Durlu-Özkaya, 2000) was almost higher than the tyramine range of fresh and mature kashar cheeses (except S9) in this study. It was reported that the tyramine range of herby cheese changed as 18$1125.5 \mathrm{mg} / \mathrm{kg}$ (Andiç et al., 2010a), $212.5 \mathrm{mg} / \mathrm{kg}$ in Brazilian cheese (Vale \& Gloria, 1998) and $329.0 \mathrm{mg} / \mathrm{kg}$ in Turkish tulum cheese (Öner et al., 2004). So it can be concluded that consumption of kashar cheeses was generally safe with respect to their tyramine levels.

Table 3. Changes of biogenic amine concentration $(\mathrm{mg} / \mathrm{kg})$ in fresh kashar cheeses during storage

\begin{tabular}{|c|c|c|c|c|c|}
\hline \multirow[t]{2}{*}{ Time (weeks) } & \multicolumn{5}{|c|}{ Kashar cheese types } \\
\hline & S1 & S2 & $\mathrm{S} 3$ & S4 & S5 \\
\hline \multicolumn{6}{|l|}{ Histamine } \\
\hline 0 & $49.5 \pm 10.7 \mathrm{aA}$ & $76.4 \pm 9.6 \mathrm{aAB}$ & $29.0 \pm 3.2 \mathrm{aA}$ & $75.1 \pm 0.9 \mathrm{aAB}$ & $74.1 \pm 10.0 \mathrm{aAB}$ \\
\hline 1 & $76.6 \pm 4.7 \mathrm{bcAB}$ & $94.4 \pm 0 \mathrm{bB}$ & $38.9 \pm 2.9 \mathrm{bA}$ & $95.4 \pm 0.7 \mathrm{bB}$ & $106.8 \pm 0.4 \mathrm{bBC}$ \\
\hline 2 & $78.0 \pm 8.8 \mathrm{cAB}$ & $105.6 \pm 6.2 \mathrm{bBC}$ & $45.4 \pm 2.5 \mathrm{bA}$ & $103.3 \pm 0.4 \mathrm{bABC}$ & $145.9 \pm 0.4 \mathrm{cC}$ \\
\hline \multicolumn{6}{|c|}{ Phenylethylamine } \\
\hline 0 & $86.11 \pm 6.5 \mathrm{abAB}$ & $35.2 \pm 1.1 \mathrm{abA}$ & $43.1 \pm 8.6 \mathrm{aA}$ & $63.4 \pm 6.5 \mathrm{aAB}$ & $54.4 \pm 2.8 \mathrm{aaAB}$ \\
\hline 1 & $112.5 \pm 6.3 \mathrm{abAB}$ & $42.6 \pm 1.2 \mathrm{abcA}$ & $46.5 \pm 1.7 \mathrm{aA}$ & $92.3 \pm 4.7 \mathrm{bA}$ & $84.8 \pm 6.8 \mathrm{cA}$ \\
\hline 2 & $122.2 \pm 12.4 \mathrm{bC}$ & $55.7 \pm 8.6 \mathrm{cA}$ & $57.4 \pm 4.8 \mathrm{bA}$ & $109.6 \pm 3.6 \mathrm{cBC}$ & $65.6 \pm 3.5 \mathrm{bcAB}$ \\
\hline \multicolumn{6}{|l|}{ Tyramine } \\
\hline 0 & $46.9 \pm 8.2 \mathrm{aBC}$ & $37.7 \pm 7.0 \mathrm{abA}$ & $63.1 \pm 6.8 \mathrm{aB}$ & $52.7 \pm 2.0 \mathrm{abAB}$ & $90.7 \pm 26.1 \mathrm{aCD}$ \\
\hline 1 & $50.3 \pm 6.5 \mathrm{aB}$ & $57.0 \pm 0.5 \mathrm{abA}$ & $76.2 \pm 4.6 \mathrm{abAB}$ & $60.4 \pm 0.1 \mathrm{abA}$ & $94.5 \pm 8.5 \mathrm{aB}$ \\
\hline 2 & $85.7 \pm 2.1 \mathrm{abC}$ & $61.6 \pm 3.4 \mathrm{bA}$ & $90.0 \pm 9.6 \mathrm{bA}$ & $79.4 \pm 8.7 \mathrm{bA}$ & $125.2 \pm 0.4 \mathrm{bA}$ \\
\hline \multicolumn{6}{|l|}{ Tryptamine } \\
\hline 0 & $62.3 \pm 7.2 \mathrm{aBC}$ & $37.1 \pm 2.7 \mathrm{aA}$ & $38.4 \pm 5.1 \mathrm{aA}$ & $48.9 \pm 0.6 \mathrm{aAB}$ & $47.5 \pm 0.8 \mathrm{aAB}$ \\
\hline 1 & $69.8 \pm 1.8 \mathrm{aB}$ & $38.8 \pm 1.2 \mathrm{aA}$ & $45.0 \pm 1.1 \mathrm{bA}$ & $67.6 \pm 3.7 \mathrm{bB}$ & $51.1 \pm 2.7 \mathrm{bA}$ \\
\hline 2 & $65.8 \pm 9.2 \mathrm{bC}$ & $40.1 \pm 2.3 \mathrm{bA}$ & $42.8 \pm 3.4 \mathrm{bA}$ & $63.7 \pm 2.2 \mathrm{abC}$ & $59.4 \pm 9.3 \mathrm{abBC}$ \\
\hline \multicolumn{6}{|l|}{ Putrescine } \\
\hline 0 & $12.5 \pm 0.7 \mathrm{aA}$ & $15.4 \pm 5.2 \mathrm{aA}$ & $119.8 \pm 9.5 \mathrm{aD}$ & $30.2 \pm 1.1 \mathrm{aA}$ & $224.6 \pm 20.1 \mathrm{aE}$ \\
\hline 1 & $22.1 \pm 6.2 \mathrm{abA}$ & $30.5 \pm 2.1 \mathrm{bA}$ & $164.7 \pm 11.2 \mathrm{bC}$ & $41.5 \pm 2.6 \mathrm{abA}$ & $274.6 \pm 13.2 \mathrm{bD}$ \\
\hline 2 & $20.1 \pm 2.8 \mathrm{bA}$ & $51.4 \pm 4.4 \mathrm{cAB}$ & $157.6 \pm 5.8 \mathrm{abDE}$ & $61.4 \pm 4.3 \mathrm{cABC}$ & $264.3 \pm 18.1 \mathrm{abF}$ \\
\hline \multicolumn{6}{|l|}{ Cadaverine } \\
\hline 0 & $100.6 \pm 36.3 \mathrm{bBC}$ & $9.2 \pm 3.7 \mathrm{aA}$ & $51.5 \pm 3.5 \mathrm{aAB}$ & $97.5 \pm 3.4 \mathrm{aBC}$ & $45.6 \pm 2.3 \mathrm{aAB}$ \\
\hline 1 & $93.6 \pm 11.2 \mathrm{aC}$ & $20.1 \pm 7.3 \mathrm{abA}$ & $66.3 \pm 0.9 \mathrm{bB}$ & $119.6 \pm 10.8 b D$ & $46.3 \pm 1.6 \mathrm{aB}$ \\
\hline 2 & $122.3 \pm 4.1 \mathrm{abC}$ & $51.4 \pm 4.3 \mathrm{cA}$ & $65.2 \pm 0.3 \mathrm{bB}$ & $120.6 \pm 5.6 \mathrm{bC}$ & $49.8 \pm 0.1 \mathrm{aA}$ \\
\hline \multicolumn{6}{|l|}{ Spermidine } \\
\hline 0 & $39.0 \pm 1.2 \mathrm{aBC}$ & $11.5 \pm 2.3 \mathrm{aA}$ & $28.9 \pm 1.4 \mathrm{aAB}$ & $61.2 \pm 1.5 \mathrm{aD}$ & $19.6 \pm 4.5 \mathrm{aA}$ \\
\hline 1 & $59.5 \pm 5.7 \mathrm{bB}$ & $38.5 \pm 4.2 \mathrm{bA}$ & $28.2 \pm 2.6 \mathrm{aA}$ & $69.8 \pm 1.8 \mathrm{bB}$ & $29.2 \pm 4.2 \mathrm{bA}$ \\
\hline 2 & $57.9 \pm 6.4 \mathrm{abB}$ & $47.2 \pm 0.6 \mathrm{bB}$ & $57.6 \pm 4.5 \mathrm{bBC}$ & $61.3 \pm 1.2 \mathrm{aC}$ & $20.9 \pm 0.3 \mathrm{aA}$ \\
\hline
\end{tabular}

Different small letters indicate statistical difference at $\alpha=0.05$ level in each column.

Different capital letters indicate statistical difference at $\alpha=0.05$ level among products at each time.

S1- S5 are fresh kashar and S6-S10 are old kashar cheeses. 
Table 4. Changes of biogenic amine concentration $(\mathrm{mg} / \mathrm{kg})$ in mature kashar cheeses during storage

\begin{tabular}{|c|c|c|c|c|c|}
\hline \multirow[t]{2}{*}{ Time (weeks) } & \multicolumn{5}{|c|}{ Kashar cheese types } \\
\hline & S6 & S7 & S8 & S9 & S10 \\
\hline \multicolumn{6}{|l|}{ Histamine } \\
\hline 0 & $834.3 \pm 7.6 \mathrm{cD}$ & $136.69 \pm 8.2 \mathrm{cB}$ & $52.8 \pm 2.2 \mathrm{abA}$ & $1334.4 \pm 31.4 \mathrm{bE}$ & $269.4 \pm 23.6 \mathrm{cC}$ \\
\hline 1 & $1001.1 \pm 9.1 \mathrm{dC}$ & $148.79 \pm 11.2 \mathrm{cC}$ & $406.7 \pm 15.0 \mathrm{eE}$ & $2035.8 \pm 58.3 \mathrm{cG}$ & $300.8 \pm 2.5 \mathrm{cdD}$ \\
\hline 2 & $1007.5 \pm 10.2 \mathrm{dG}$ & $270.15 \pm 9.5 \mathrm{dD}$ & $362.2 \pm 0.5 \mathrm{dE}$ & $3042.9 \pm 74.9 \mathrm{eH}$ & $483.1 \pm 17.4 \mathrm{eF}$ \\
\hline \multicolumn{6}{|c|}{ Phenylethylamine } \\
\hline 0 & $104.4 \pm 15.8 \mathrm{aB}$ & $325.9 \pm 34.1 \mathrm{bCD}$ & $355.2 \pm 20.1 \mathrm{bD}$ & $43.9 \pm 1.7 \mathrm{dA}$ & $280.2 \pm 4.1 \mathrm{cC}$ \\
\hline 1 & $263.3 \pm 12.6 \mathrm{bcC}$ & $479.4 \pm 56.1 \mathrm{cD}$ & $480.5 \pm 8.5 \mathrm{cD}$ & $42.5 \pm 5.1 \mathrm{dA}$ & $243.6 \pm 12.8 \mathrm{bcBC}$ \\
\hline 2 & $427.9 \pm 24.8 \mathrm{dF}$ & $347.3 \pm 9.6 \mathrm{bE}$ & $460.2 \pm 9.8 \mathrm{aF}$ & $38.4 \pm 1.9 \mathrm{cA}$ & $282.1 \pm 9.1 \mathrm{cD}$ \\
\hline \multicolumn{6}{|l|}{ Tyramine } \\
\hline 0 & $98.0 \pm 6.1 \mathrm{aD}$ & $289.0 \pm 5.1 \mathrm{eE}$ & $71.2 \pm 6.4 \mathrm{bcBC}$ & $4324.0 \pm 90.9 \mathrm{bF}$ & $103.0 \pm 3.1 \mathrm{bD}$ \\
\hline 1 & $176.7 \pm 3.1 \mathrm{bD}$ & $190.3 \pm 4.6 \mathrm{cD}$ & $129.0 \pm 7.2 \mathrm{cC}$ & $5771.0 \pm 17.0 \mathrm{cE}$ & $190.3 \pm 13.8 \mathrm{dD}$ \\
\hline 2 & $256.4 \pm 9.2 \mathrm{cB}$ & $253.0 \pm 0.4 \mathrm{~dB}$ & $99.8 \pm 3.3 \mathrm{dA}$ & $6665.6 \pm 130.2 \mathrm{dC}$ & $123.2 \pm 4.6 \mathrm{cA}$ \\
\hline \multicolumn{6}{|l|}{ Tryptamine } \\
\hline 0 & $375.1 \pm 23.4 \mathrm{cE}$ & $251.5 \pm 4.8 \mathrm{eD}$ & $34.0 \pm 3.7 \mathrm{abA}$ & $32.6 \pm 1.7 \mathrm{bA}$ & $78.7 \pm 1.5 \mathrm{cC}$ \\
\hline 1 & $421.0 \pm 4.3 \mathrm{dE}$ & $125.3 \pm 6.8 \mathrm{dC}$ & $74.3 \pm 15.6 \mathrm{cB}$ & $42.4 \pm 4.2 \mathrm{bcA}$ & $76.7 \pm 11.1 \mathrm{dD}$ \\
\hline 2 & $552.1 \pm 2.6 \mathrm{eF}$ & $125.3 \pm 6.8 \mathrm{dE}$ & $62.7 \pm 0.8 \mathrm{cC}$ & $49.1 \pm 6.1 \mathrm{cdBC}$ & $90.1 \pm 1.2 \mathrm{cD}$ \\
\hline \multicolumn{6}{|l|}{ Putrescine } \\
\hline 0 & $53.4 \pm 0.1 \mathrm{aB}$ & $313.6 \pm 4.0 \mathrm{cF}$ & $50.1 \pm 1.2 \mathrm{cB}$ & $384.4 \pm 3.5 \mathrm{cG}$ & $92.7 \pm 5.6 \mathrm{bC}$ \\
\hline 1 & $134.6 \pm 34.6 \mathrm{abBC}$ & $326.4 \pm 5.4 \mathrm{cE}$ & $100.5 \pm 8.4 \mathrm{cB}$ & $440.2 \pm 2.7 \mathrm{cF}$ & $147.7 \pm 9.0 \mathrm{cC}$ \\
\hline 2 & $206.1 \pm 6.1 \mathrm{bE}$ & $255.4 \pm 21.5 \mathrm{bF}$ & $86.7 \pm 5.6 \mathrm{bBC}$ & $435.1 \pm 8.9 \mathrm{cG}$ & $109.9 \pm 9.5 \mathrm{dCD}$ \\
\hline \multicolumn{6}{|l|}{ Cadaverine } \\
\hline 0 & $98.4 \pm 7.5 \mathrm{bcdBC}$ & $167.0 \pm 4.5 \mathrm{cC}$ & $349.0 \pm 9.1 \mathrm{bE}$ & $254.7 \pm 12.7 \mathrm{aD}$ & $149.0 \pm 1.2 \mathrm{cC}$ \\
\hline 1 & $95.5 \pm 4.8 \mathrm{bcC}$ & $165.0 \pm 1.7 \mathrm{cE}$ & $441.0 \pm 9.3 \mathrm{dG}$ & $239.3 \pm 15.6 \mathrm{aF}$ & $150.1 \pm 7.5 \mathrm{bD}$ \\
\hline 2 & $179.0 \pm 5.4 \mathrm{dD}$ & $131.0 \pm 7.4 \mathrm{bcC}$ & $448.2 \pm 3.2 \mathrm{dF}$ & $218.8 \pm 3.2 \mathrm{aE}$ & $173.1 \pm 6.3 \mathrm{dD}$ \\
\hline \multicolumn{6}{|l|}{ Spermidine } \\
\hline 0 & $48.9 \pm 0.7 \mathrm{aCD}$ & $58.1 \pm 1.5 \mathrm{bD}$ & $28.4 \pm 3.5 \mathrm{abAB}$ & $132.7 \pm 1.3 \mathrm{eF}$ & $109.5 \pm 1.5 \mathrm{cE}$ \\
\hline 1 & $68.3 \pm 2.7 \mathrm{aB}$ & $87.9 \pm 6.7 \mathrm{cC}$ & $33.6 \pm 5.1 \mathrm{bcA}$ & $119.0 \pm 5.4 \mathrm{dD}$ & $138.6 \pm 1.3 \mathrm{dE}$ \\
\hline 2 & $96.3 \pm 2.9 \mathrm{bE}$ & $178.3 \pm 1.2 \mathrm{eF}$ & $60.5 \pm 5.8 \mathrm{dC}$ & $89.0 \pm 2.2 \mathrm{cDE}$ & $79.6 \pm 6.2 \mathrm{bD}$ \\
\hline
\end{tabular}

Different small letters indicate statistical difference at $\alpha=0.05$ level in each column.

Different capital letters indicate statistical difference at $\alpha=0.05$ level among products at each time.

S1- S5 are fresh kashar and S6-S10 are old kashar cheeses.

\section{Changes in Tryptamine Concentration}

Tryptamine was detected in all kashar cheese samples. The highest tryptamine concentration was detected in sample S6 amoung all cheese samples. Tryptamine was found from 0.32 to $40.44 \mathrm{mg} / \mathrm{kg}$ in tulum cheese (Öner et al., 2004) and in the range as $0-172.6 \mathrm{mg} / \mathrm{kg}$ in herby cheese (Andıç et al., 2010a). The toxic threshold level of tryptamine is not known. During the storage period, tryptamine concentration of fresh and mature kashar cheeses increased, decreased or remain same. Decrease in tryptamine concentration could be explained as the consumption of produced biogenic amines by microorganisms as a nitrogen source. Also, some authors have suggested that the decrease of biogenic amines during ripening could be related to the activity of bacterial amine oxidases (Leuschner et al., 1999).

\section{Changes in Putrescine Concentration}

The level of putrescine concentration significantly increased $(p<0.05)$ during storage period for all kashar cheese samples. S3 and S5 samples had higher putrescine concentration at the beginning of storage period amoung fresh kashar cheeses. S9 sample had also the highest putrescine concentration in all samples. Enterobacteriaceae are generally considered as microorganisms with a high decarboxylase activity, particularly in relation to the production of putrescine 
(Suzzi et al., 2003). Presence of high concentrations of putrescine in S3, S5 and S9 samples could be explained by high decarboxylase activity of Enterobacteriaceae.

The biogenic amines most commonly found in fermented dairy products are histamine and tyramine, but putrescine is also frequently detected and can occasionally accumulate in concentrations of up to $2.5 \mathrm{~g}$ per $\mathrm{kg}$ of cheese. Risk taking into account that levels of $875 \mathrm{mg}$ putrescine per $\mathrm{kg}$ have been detected in cheeses (Fernandez et al., 2007). None of the samples exceed this level in our study. But presence of high amount of putrescine can increase the toxic effects of other biogenic amines frequently present in fermented foods and beverages, as histamine, tyramine and phenylethylamine (Linares et al., 2013). On the other hand, high concentrations of putrescine affect the organoleptic quality of food due to its foul odour (Ladero et al., 2012).

\section{Changes in Cadaverine and Spermidine Concentration}

Cadaverine concentration increased significantly $(p<0.05)$ during the two weeks of storage for all kashar cheese samples (Tables 3 and 4). Initially, cadaverine concentrations changed as 9.2-100.6 mg/ $/ \mathrm{kg}$ and $98.4-349.0 \mathrm{mg} / \mathrm{kg}$ for fresh and mature kashar cheeses, respectively. During storage, cadaverine concentrations changed as $49.8-122.3 \mathrm{mg} / \mathrm{kg}$ and $131.0-448.2 \mathrm{mg} / \mathrm{kg}$ for fresh and mature kashar cheeses, respectively. Cadaverine concentration was found as relatively high levels in some samples. A wide variability of cadaverine concentration was detected and reported for different cheeses. It could be due to the differences in the manufacturing process: type of milk (sheep or cow), heat treatment of milk (such as pasteurization), ripening time, microflora and cheese mass (Andıç et al., 2010a). It was observed that sample S1 had the highest cadaverine concentration at the beginning of storage period amoung fresh kashar cheeses. Also, initial highest cadaverine concentration amoung mature kashar cheeses was detected in sample S8 $(349.0 \mathrm{mg} / \mathrm{kg})$. Cadaverine has less pharmacological activity than the aromatic amines but it is probably potentiators of their toxicity (Joosten, 1988). Also, it could be used as quality indicator for cheese making. Maximum levels of cadaverine were found as $1844.5 \mathrm{mg} / \mathrm{kg}$ in Herby cheese (Andıç et al., 2010a), $1110 \mathrm{mg} / \mathrm{kg}$ in Brazilian cheese (Vale \& Gloria, 1998) and reach levels $>1000 \mathrm{mg} / \mathrm{kg}$ in Motal cheese (Andiç et al., 2010b).

Spermidine in kashar cheese were also detected and it was observed that storage period was significantly $(p<0.05)$ effective. Maximum initial spermidine concentrations were found for samples $\mathrm{S} 9(132.7 \mathrm{mg} / \mathrm{kg})$ and $\mathrm{S} 4(61.2 \mathrm{mg} / \mathrm{kg})$ amoung in mature and fresh kashar cheese samples, respectively. Spermidine concentration is not usually detected in cheese samples. There is no any specified toxic value for spermidine in cheese.

\section{Total Biogenic Amine Contents of Fresh and Mature Kashar Cheeses}

Total biogenic amine contents were calculated by the summation of histamine, phenylethylamine, tyramine, tryptamine, putrescine, cadaverine and spermidine contents of mature and fresh kashar cheeses and the results were given in Table 5. Initiallly, total biogenic amine contents of fresh and mature kashar cheese samples were found in the range as 222.4-556.6 and 940.6-6507.5 mg/kg, respectively. During storage, total biogenic amine contents of all samples increased significantly $(p<0.05)$. Total biogenic amine contents of mature kashar cheese samples were higher than that of fresh kashar cheese samples. An acceptable level of 1000 $\mathrm{mg} / \mathrm{kg}$ for total biogenic amine content was proposed (SillaSantos, 1996) total biogenic amine contents of fresh kashar cheese samples never exceed this limit during storage. But, total biogenic amine contents of mature kashar cheese samples were higher than $1000 \mathrm{mg} / \mathrm{kg}$ level before and during storage period. This could be due to the long ripening period of mature kashar cheese and its consumption can cause toxicity.

\section{Conclusion}

The results of this study showed that storage period had significant effect on formation of biogenic amines in all kashar cheese samples. In general, the biogenic amine content of cheese can be extremely variable and depends on the type of cheese, the ripening time, the manufacturing process and the microorganisms present. According to the results, mature kashar cheese samples had higher biogenic amine content than fresh kashar cheeses. Concentrations of biogenic amines changed with the same trend almost in all samples during the storage period. According to the toxic limits, mature kashar cheese samples should not be consumed. Also, all mature kashar cheeses had critical toxic level of histamine. In fresh kashar cheese, there were no toxicity risk with respect to the biogenic amine. Mature kashar cheese generally prefferred due to its special flavor and taste but this study showed that it is not safe with respect to biogenic amine. Therefore, further research is needed to optimize processing technology and ensure low amine levels for mature kashar cheeses. 
Table 5. Total biogenic amine contents of fresh and mature kashar cheeses

\begin{tabular}{lllllc}
\hline $\begin{array}{l}\text { Time } \\
\text { (weeks) }\end{array}$ & \multicolumn{5}{c}{ Kashar cheese types } \\
\hline \multicolumn{5}{c}{} & \multicolumn{5}{c}{$\mathrm{S} 1$} & \multicolumn{1}{c}{$\mathrm{S} 3$} & $\mathrm{~S} 4$ & $\mathrm{~S} 5$ \\
0 & $396.9 \pm 101.2 \mathrm{aB}$ & $222.4 \pm 25.6 \mathrm{aA}$ & $373.9 \pm 38.3 \mathrm{aB}$ & $428.9 \pm 17.7 \mathrm{aB}$ & $556.6 \pm 20.6 \mathrm{aC}$ \\
1 & $484.4 \pm 8.5 \mathrm{aB}$ & $322.0 \pm 16.7 \mathrm{bA}$ & $465.7 \pm 5.0 \mathrm{bAB}$ & $546.7 \pm 29.3 \mathrm{bBC}$ & $687.3 \pm 12.6 \mathrm{bcC}$ \\
2 & $552.1 \pm 41.0 \mathrm{aBC}$ & $413.0 \pm 8.5 \mathrm{cA}$ & $515.8 \pm 11.9 \mathrm{bB}$ & $599.4 \pm 16.7 \mathrm{bC}$ & $731.3 \pm 29.8 \mathrm{bD}$ \\
& & & & & \\
\hline & $\mathrm{S} 6$ & $\mathrm{~S} 7$ & $\mathrm{~S} 8$ & $\mathrm{~S} 9$ & $\mathrm{~S} 10$ \\
0 & $1612.5 \pm 33.2 \mathrm{aF}$ & $1541.9 \pm 66.5 \mathrm{bF}$ & $940.6 \pm 14.3 \mathrm{aD}$ & $6507.5 \pm 32.5 \mathrm{aG}$ & $1082.5 \pm 80.1 \mathrm{aE}$ \\
1 & $2160.5 \pm 115.9 \mathrm{cF}$ & $1523.3 \pm 77.3 \mathrm{bDE}$ & $1666.7 \pm 114.3 \mathrm{cE}$ & $8691.2 \pm 6.8 \mathrm{cG}$ & $1427.9 \pm 119.8 \mathrm{bD}$ \\
2 & $2725.2 \pm 42.5 \mathrm{dG}$ & $1560.6 \pm 40.4 \mathrm{bF}$ & $1580.5 \pm 9.7 \mathrm{cF}$ & $10538.6 \pm 55.8 \mathrm{dH}$ & $1340.6 \pm 32.2 \mathrm{bE}$
\end{tabular}

Different small letters indicate statistical difference at $\alpha=0.05$ level in each column.

Different capital letters indicate statistical difference at $\alpha=0.05$ level among products at each time.

S1- S5 are fresh kashar and S6-S10 are old kashar cheeses.

\section{Compliance with Ethical Standard}

Conflict of interests: The authors declare that for this article they have no actual, potential or perceived conflict of interests.

\section{References}

AACC (1995). Approved Methods of the American Association of Cereal Chemists. 9th edn., 45-48. Minnesota, USA, The American Association of Cereal Chemists.

AOAC (1990). Offical Methods of Analysis of Association of Offical Analytical Chemists. Edited by Kenneth Helrich, Fifteenth ed., Arlington, Virginia, USA, pp. 74.

Andic, S., Gençcelep, H., Köse, S. (2010a). Determination of biogenic amines in herby Cheese. International Journal of Food Properties, 13, 300-1314.

Andic, S., Gençcelep, H., Tunçtürk, Y., Köse, S. (2010b). The effect of storage temperatures and packaging methods on properties of Motal cheese. Journal of Dairy Science, 93, 849-859.

Andiç, S., Tunçtürk, Y., Gençcelep, H. (2011). The effect of different packaging methods on the formation of biogenic amines and organic acids in Kashar cheese. Journal of Dairy Science, 94, 1668-1678.

Anonymous (2005). The Eight Five Year Development Plan. Ankara, Turkey: The State Plannin Organization.

Aran, N. (1998). A microbial study of Kashar cheese. Milchwissenschaft 53, 565-567.
Benkerroum, N. (2016). Biogenic Amines in Dairy Products: Origin, Incidence, and Control Means. Comphrehensive Reviews in Food Science and Food Safety, 15, 801-826.

Botsoglou, N.A., Fletouris, D.J., Papageorgiou, G.E., Vassilopoulos, V.N., Mantis, A.J., Trakatellis, A.G. (1994). Rapid, Sensitive, and Specific Thiobarbituric Acid Method for Measuring Lipid Peroxidation in Animal Tissue, Food and Feedstuff Samples. Journal of Agriculture and Food Chemistry, 42, 1931-1937.

Bozkurt, H., Erkmen, O. (2004). Effect of nitrate/nitrite on the quality sausage (sucuk) during ripening and storage. Journal of the Science of Food and Agriculture, 84, 279-286.

Butikofer, U., Ruegg, M., Ardo, U. (1993). Determination of nitrogen fractions in cheese: Evaluation of a collaborative study. Lebensmittel Wissenschaft und Technologie, 26, 271-275.

Çetinkaya, A., Yaman, H., Elmalı, M., Karadağoğlu, G. (2003). A preliminary study of Kashar cheese and its organoleptic qualities matured in bee wax. International Journal of Food Safety, 6, 1-4.

Durlu-Ozkaya, F. (2000). Biogenic amine content of some Turkish cheeses. Journal of Food Processing Preservation, 26, 259-265.

Eerola, S., Hinkkanen, R., Lindfors, E., Hirvi, T. (1993). Liquid chromatographic determination of biogenic amines in dry sausage. Journal of AOAC International, $76,575-77$. 
Fernandez, M., Linares, D.M., del Rio, B., Ladero, V., Alvarez, M.A. (2007). HPLC quantification of biogenic amines in cheeses: correlation with PCR-detection of tyramineproducing microorganisms. The Journal of Dairy Research, 74, 276-282.

Flasarova, R., Pachlova, V., Bunkova, L., Mensikova, A., Georgova, N., Drab, V., Bunka, F. (2016). Biogenic amine production by Lactococcus lactis subsp. cremoris strains in the model system of Dutch-type cheese. Food Chemistry, 194, 68-75.

Halkman, K., Halkman, Z. (1991). Studies on the different combinations of Kashar Cheese starter cultures. Gida, $16,99-105$.

Joosten, H.M.L.J. (1988). Conditions Allowing the Formation of Biogenic Amines in Cheese. 3. Factors Influencing the Amounts Formed. Netherlands Milk and Dairy Journal, 41, 329-357.

Koca, N., Metin, M. (2004). Textural, melting and sensory properties of low-fat fresh kashar cheeses produced by using fat replacers. International Dairy Journal, 14, 365-373.

Koehler, P.E., Eitenmiller, R.R. (1978). High pressure liquid chromatographic analysis of tyramine, phenylethyla- mine and tryptamine in sausage, cheese and chocolate. Journal of Food Science, 43, 1245-1247.

Ladero, V., Canedo, E., Perez, M., Martin, M.C., Fernandez, M., Alverez, M.A. (2012). Multiplex qPCR for the detection and quantification of putrescine-producing lactic acid bacteria in dairy products. Food Control, 27, 307-313.

Leuschner, R.G.K., Kurihara, R., Hammes, W.P. (1999). Formation of biogenic amines by proteolytic enterococci during cheese ripening. Journal of Science Food and Agriculture, 79, 1141-1144.

Linares, D.M., del Rio, B., Ladero, V., Redruello, B., Martin, M.C., Fernandez, M., Alvarez, M. A. (2013). The putrescine biosynthesis pathway in Lactococcus lactis is transcriptionally regulated by carbon catabolic repression, mediated by CcpA. International Journal of Food Microbiology, 165, 43-50.
Medeiros, B.G.S., Souza, M.P., Pinheiro, A.C., Bourbon, A.I., Cerqueira, M.A., António A. Vicente, A.A., Carneiro-da-Cunha, M.G. (2014). Physical Characterisation of an Alginate/Lysozyme Nano-Laminate Coating and Its Evaluation on 'Coalho' Cheese Shelf Life. Food Bioprocess Technology, 7, 1088-1098.

McSweeney, P.L.H. (2004). Biochemistry of cheese ripening. International Journal of Dairy Technology, 57, 127-144.

Nout, M.J.R. (1994). Fermented foods and food safety. Food Research International, 27, 291-298.

Oner, Z., Sağdıc, O., Şimşek, O. 2004. Lactic acid bacteria profiles and tyramine and tryptamine contents of Turkish tulum cheeses. Europen Food Research and Technology, 219, 455-459.

Pintado, A.I.E., Pinho, O., Ferreira, I.M.P.L.V.O., Pintado, M.M.E., Gomes, A.M.P., Malcata, F.X. (2008). Microbiological, biochemical and biogenic amine profiles of Terrincho cheese manufactured in several dairy farms. International of Dairy Journal, 18, 631-640.

Roig-Sagues, A.X., Molina, A.P., Hernandez-Herrero, M.M. (2002). Histamine and tyramine-forming microorganisms in Spanish traditional cheeses. Europen Food Research and Technology, 215, 96-100.

Ruiz-Capillas, C., Moral, A. (2001). Production of biogenic amines and their potential use as quality control indices for hake (Merluccius merluccius, L.) stored in ice. Journal of Food Science, 66, 1030-1032.

Sert, D., Ayar, A., Akin, N. (2007). The Effects of Starter Culture on Chemical Composition, Microbiological and Sensory Characteristics of Turkish Kasar Cheese during Ripening. Internet Journal of Food Safety, 9, 713.

Schirone, M., Tofalo, R., Mazzone, G., Corsetti, A., Suzzi, G. (2011). Biogenic amine content and microbiological profile of Pecorino di Farindola cheese. Food Microbiology, 28, 128-136.

Shalaby, A.R. (1996). Significance of biogenic amines to food safety and human health. Food Research International, 29, 675-690. 
Silla-Santos, M.H. (1996). Biogenic amines: their importance in foods. International Journal of Food Microbiolology, 29, 213-231.

Silvana, V.M., Glhia, A. (1998). Biogenic amines in Brazilian cheeses. Food Chemistry, 63, 343-348.

Spizzirri, U.G., Restuccia, D., Curcio, M., Parisi, O.I., Iemma, F., Picci, N. (2013). Determination of biogenic amines in different cheese samples by LC with evaporative light scattering detector. Journal of Food Composition and Analysis, 29, 43-51.

Stratton, J.E., Hutkins, R.W., Summer, S.S., Taylor, S.L. (1992). Histamine and histamine-producing bacteria in retail Swiss and low-salt cheeses. Journl of Food Protection, 55, 435-439.

Suzzi, G., Schirone, M., Martuscelli, M., Gatti, M., Fornasari, M.E., Neviani, E. (2003). Yeasts associated with Manteca. FEMS Yeasts Research, 3, 159-166.
Şahin-Ercan, S., Bozkurt, H., Soysal, Ç. (2013). Significance of Biogenic Amines in Foods and Their Reduction Methods. Journal of Food Science and Engineering, 3, 395-410.

Turkish Standards, (TS) (1999). Kashar cheese, No. 3272. The Institute of Turkish Standards, Ankara.

Üçüncü, M. (2004). Milk Technology. 1. Part, Milk Composition and Technology. Ege Üniversitesi Basımevi, Bornova, Đzmir, Türkey.

Vale, S. \& Gloria, M.B.A. (1998). Biogenic amines in Brazilian cheeses. Food Chemistry, 63, 343-348.

Wu, W.H., Rule, D.C., Busboom, J.R., Field, R.A., Ray, B. (1991). Starter culture and time/temperature of storage influences on quality of fermented mutton sausage. Journal of Food Science, 56, 916-919. 